\title{
IMPACT COVID-19 ON IMPLEMENTATION AND EVALUATION OF ONLINE LEARNING
}

\author{
${ }^{1}$ Muhammad Isradi, ${ }^{2}$ Sumiyati \\ ${ }^{1}$ Faculty of Engineering, University Mercu Buana Jakarta, Indonesia \\ ${ }^{2}$ Faculty of Admininstration, Sekolah Tinggi Ilmu Administrasi Menara Siswa, Indonesia \\ Email : muhammad.isradi@mercubuana.ac.id, sumi.widi@gmail.com
}

\begin{abstract}
Purpose: Purpose of this research is to explore and analysis impact covid-19 on implementation and evaluation of online learning

Design/methodology/approach: Collecting data through the distribution of questionnaires / questionnaires to students in Mercu Buana University, observing observations and conducting literature reviews through available literature or books related to the effectiveness of online lectures.

Findings: The Covid-19 pandemic outbreak is a serious epidemic that must be dealt with by universities, as a result of this outbreak resulted in a change in the system of learning patterns that are ongoing. Mercu Buana University is preparing itself and adapting to face these uncertain conditions, one of which is setting up the system Perkuliahan Online Sementara / Temporer (POST). So that the teaching and learning process and lectures can continue. Implementation of the system Perkuliahan Online Sementara / Temporer (POST) can be applied and used as a model to replace the conventional lecture system. Can be used as an evaluation in online learning, know the most dominant variable in influencing online learning.
\end{abstract}

Research limitations/implications: Number of respondent in this research relative small.

Practical implications: Result of this research can be used as references in practicing online learning system in education institution.

Originality/value: This paper is original because this paper discusses the condition in Mercu Buana University.

Paper type: Research paper.

Keyword: online learning, education, impact covid-19.

Received: July $19^{\text {th }}, 2020$

Revised: September $16^{\text {th }}, 2020$

Published: September $30^{\text {th }}, 2020$

\section{INTRODUCTION}

According to worldometer (2020) The number of positive corona cases in the world has reached 2,496,660 people with a death toll reaching 171,240 people. The Indonesian Minister of Health said that the first case of the corona virus entered Indonesia in February (Tantiya Nimas Nuraini, 2020) with continued growth even in Indonesia the number of people who were positively affected by the corona virus had broken into seven thousand patients with the total number of deaths reaching 616 people (Addi M Idhom, n.d.) .

UNESCO data shows that nearly 300 million students worldwide are disrupted in teaching and learning activities, and will threaten education rights in the future. In the world of education, of course, Indonesia is one of the countries affected by the spread of the corona virus so that finally the government on 16 March 2020 decided learning activities were carried out at home. This government decision was also followed by Mercu Buana University, Jakarta. The Covid-19 pandemic outbreak is a serious epidemic that must be faced by universities, as a result of this outbreak, it has changed the system of learning patterns that are taking \begin{tabular}{ll|l}
\hline Impact Covid-19 On Implementation And Evaluation Of Online Learning & Page & 310
\end{tabular} 
place. Therefore Mercu Buana University Jakarta conducts lectures online. However, the problem is the readiness of lecturers in preparing online material, and the readiness of students in preparing internet quotas

Mercu Buana University is one of the largest universities in Jakarta, founded in 1985 by $\mathrm{Mr}$. Probosutedjo. In its development now Mercu Buana University has 4 campuses located in Meruya, Menteng, Jatisampurna, and Warung Buncit with a total of 24 study programs both diploma 3, bachelor, master and doctoral degree programs and the number of students reaching more than 30,000 people. As an A-BAN-PT accredited University, Mercu Buana University prepares itself and adapts in dealing with these uncertain conditions, one of which is setting up the system Perkuliahan Online Sementara/Temporer (POST). So that the teaching and learning process and lectures can continue. In the implementation of the system (POST) of course there are very many challenges faced, especially for lecturers as teaching staff and students. In a short time the lecturer must prepare an online module for all the rest of the lecture, and try online all the conventional lecture modules. This is done to ensure the achievement of learning outcomes of a subject in this emergency condition. Likewise with the constraints there are often internet disturbances and where everything must require a large internet quota in dealing with this condition.

Of course in the system implementation policy (POST) there needs to be an evaluation, so it can be seen how much effectiveness in carrying out its performance. The performance here is about the efforts made by Mercu Buana University as an Educational Institution to students whether they are qualified or not, and whether they have provided satisfaction or not as an evaluation of the achievements of learning outcomes whether they have been achieved or not.

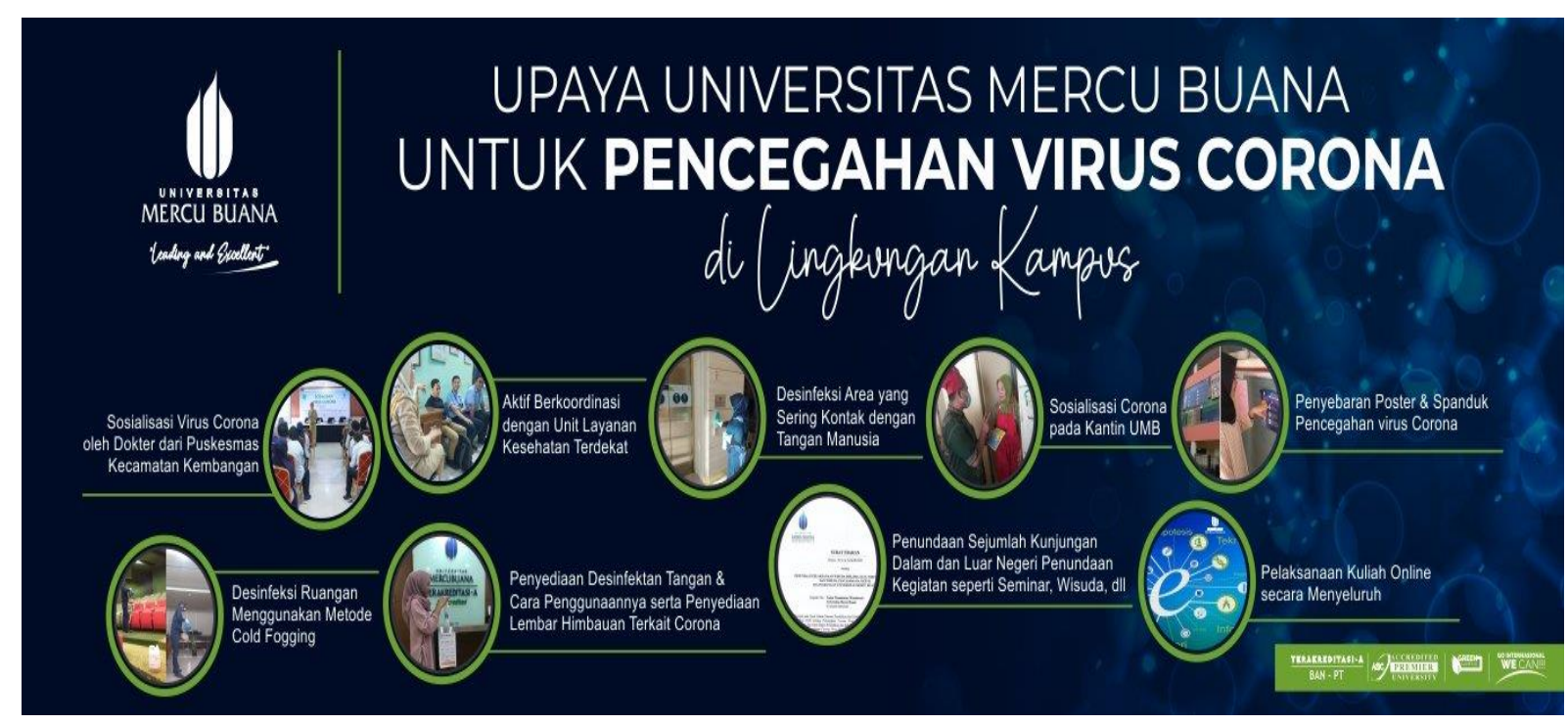

Fig 1. Corona Virus Prevention Efforts

The effectiveness study refers to the theoretical and practical way to obtain input on productivity to find out the conditions that affect an impressive thing, progress, business success, actions or things that apply (Adibowo \& Fidowaty, 2013). Effectiveness itself is defined as the relationship between output and goals, the greater the contribution to the goal the greater the contribution of output to the achievement of goals, the more effective the organization, program or activity (Mahmudi, 2005). The target to be achieved is to determine the effect of learning strategies on students with technical teaching and learning, providing education, innovation, and evaluation of the implementation of online learning that is continuously related to the impact of COVID-19.

James L. Gibson, John M. Ivancevich (1996), in achieving the goals and objectives of effectiveness is measured by including several variables such as:

1. Productivity

2. Quality

3. Efficiency

4. Flexibility

5. Excellence

6. Development

7. Satisfaction 


\section{METHODOLOGY}

Collecting data through the distribution of questionnaires / questionnaires to students in Mercu Buana University, observing observations and conducting literature reviews through available literature or books related to the effectiveness of online lectures.

\section{RESULT AND DISCUSSION}

\subsection{Aplication Implementation}

The lecturer prepares a standard lecture module in accordance with the learning design unit set by the university, prepares a power point in addition to material enrichment and provides assignment sheets for students.
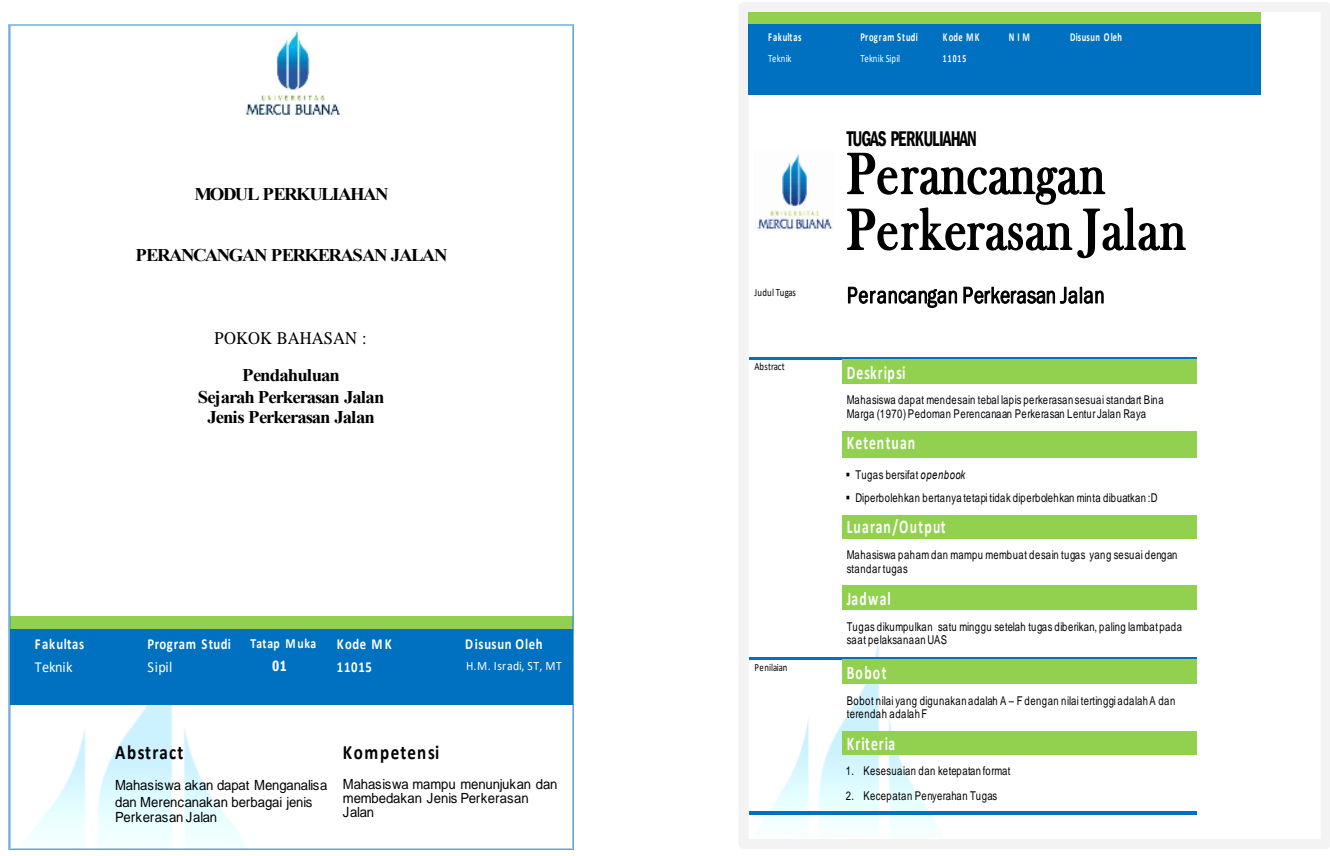

Fig 2. Lecture Module and Task Sheet

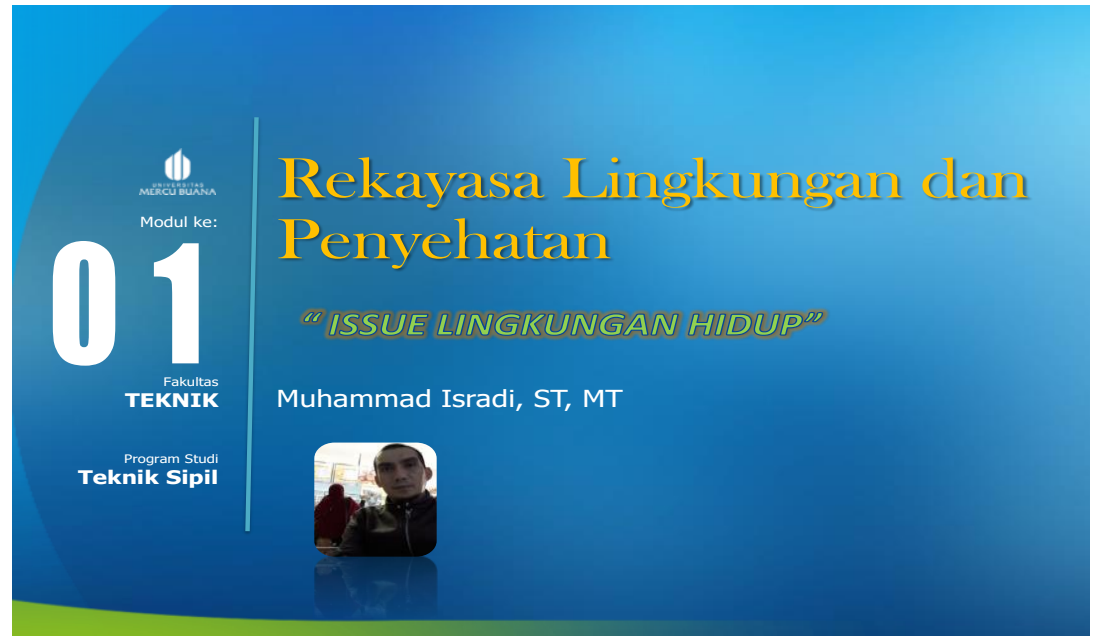

Fig 3. Lecture Module in Power Point 


\subsection{Online Learning Facility}

In the implementation of the system (POST) can be seen in the following picture
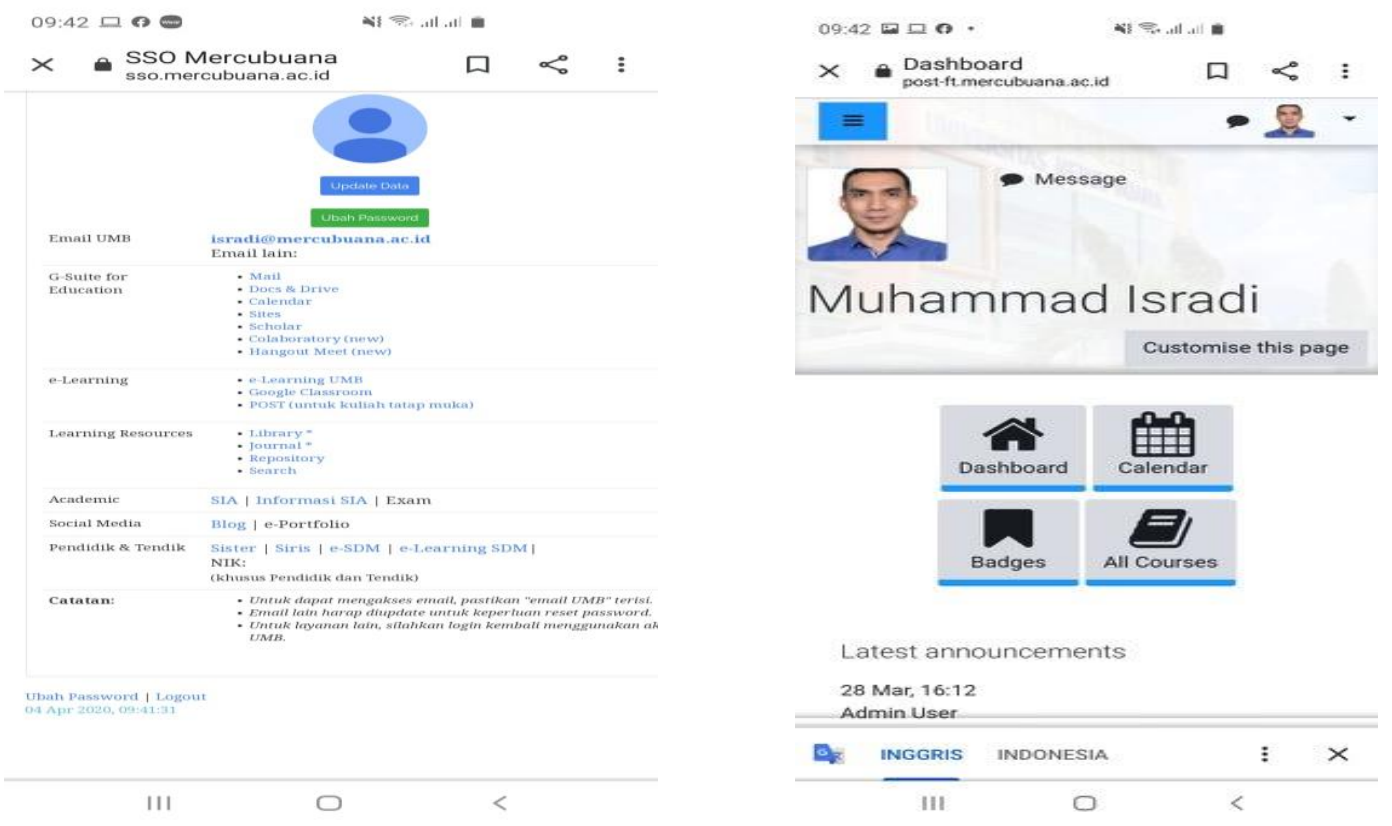

Fig 4. Mercubuana SSO and POST

To be able to access the Mercubuana Singel Sign On (SSO), lecturers and students have provided an account in the form of a user ID, password and mercubuana email, online lectures are carried out following the format and template that has been prepared by the university.
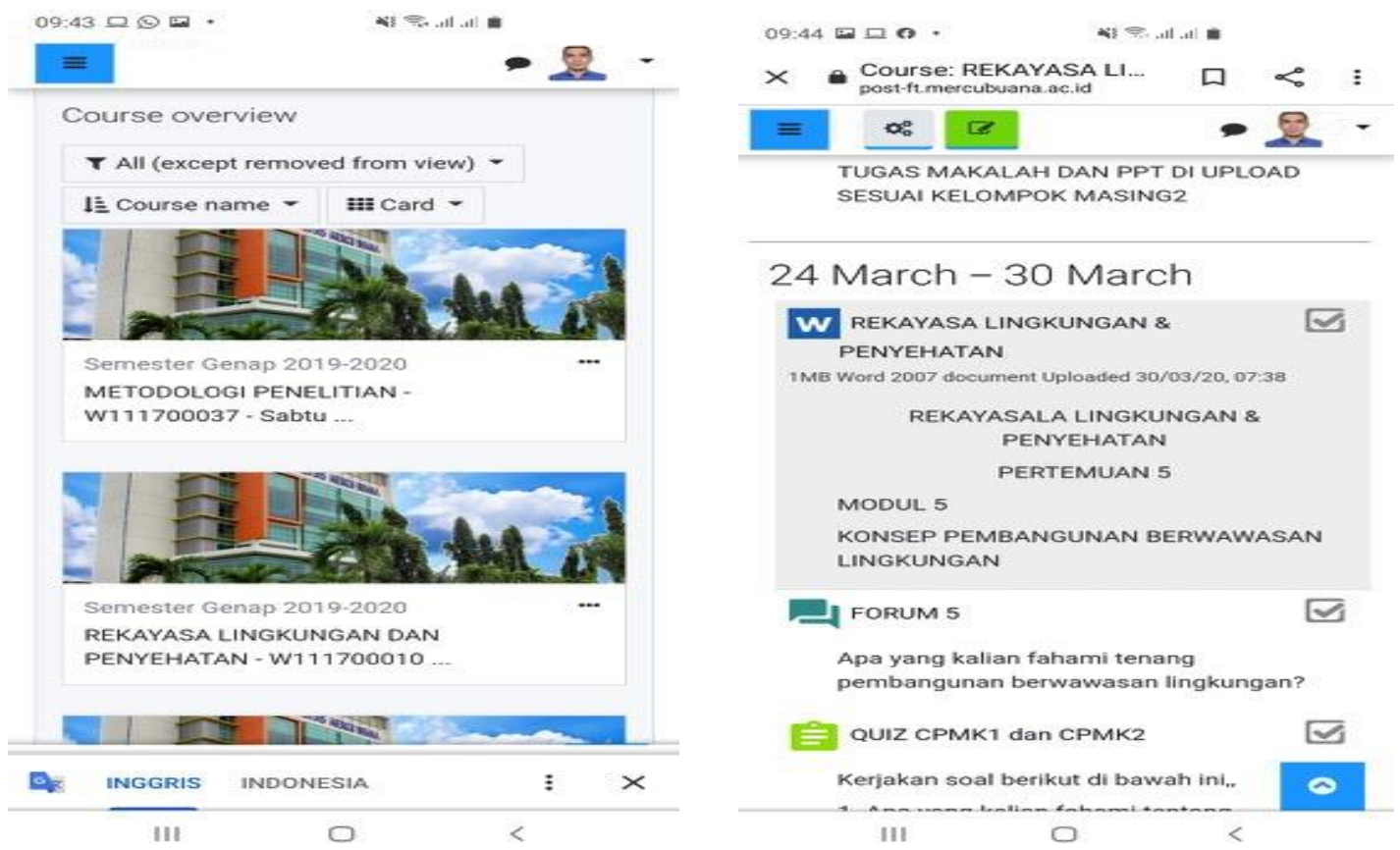

Fig 5. Format and Template in POST 


\subsection{Discussion And Grading}

Some of the online face-to-face lectures can be carried out through other facilities that have been provided by the university such as Google Hangout Meeting, where lecturers can interact directly with students related to the learning process. Discussion of lectures and assessment of lectures can be seen in the following POST template:

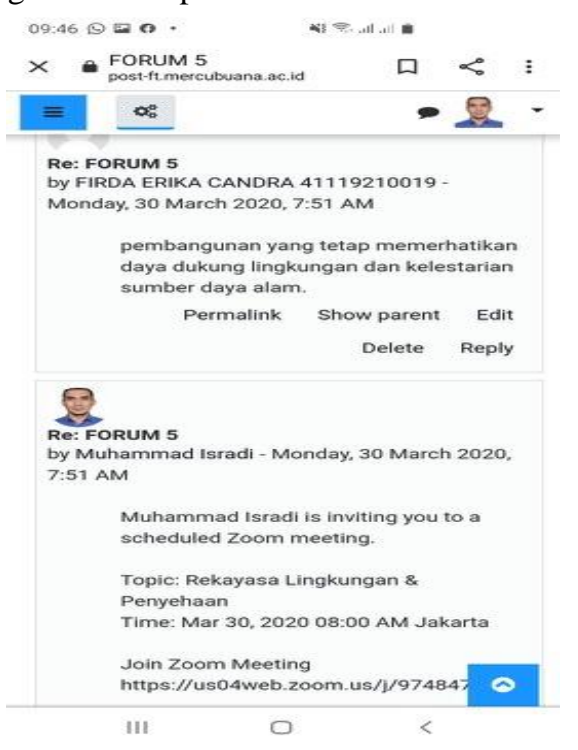

Fig 6. Discussion and Grading

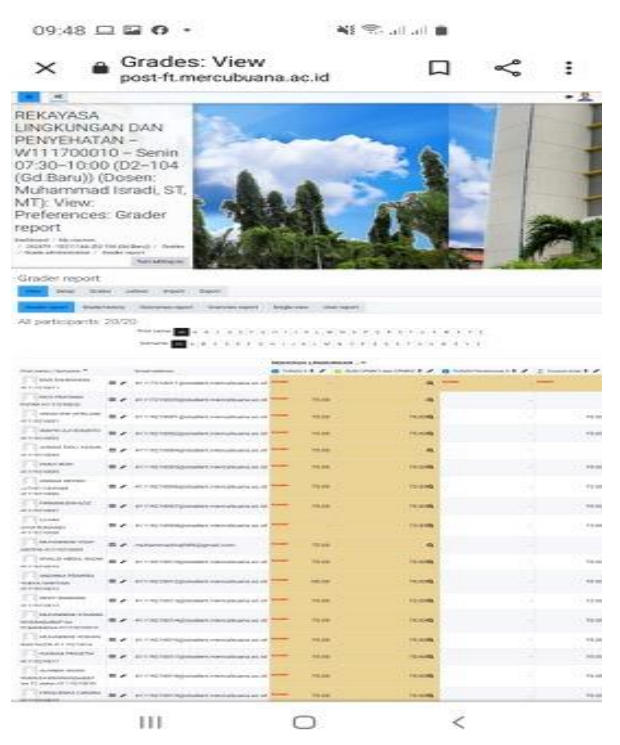

\section{IV.CONCLUSION}

In dealing with the condition of campus close down, the following conclusions are obtained

1. Implementation of Temporary / Temporary Online Lecture (POST) system can be applied and used as a model to replace conventional systems

2. The challenge for lecturers in preparing online material is to produce learning outcome achievement

3. Can be used as an evaluation in online learning, know the most dominant variable in influencing online learning

4. Know the effectiveness in online learning

\section{References}

Adiwibowo R, Fodowaty T (2013) Pengaruh Efektivitas Kuliah online Dalam Website www.unikom.ac.id Terhadap Prestasi Akademik MAhasiswa UNIKOM. Universitas Komputer Indonesia, Bandung.

Gibson, L, James John. M. Ivancevich and James H. Donnelly, Jr. 1995. Organisasi, Perilaku, Struktur dan Proses. Jakarta: Birarupa Aksara

Mahmudi, (2005). Manajemen Kinerja Sektor Publik. Yogyakarta: UPP AMP YKPN.

https://www.merdeka.com/trending/cerita-lengkap-asal-mula-munculnya-virus-corona-di-indonesia.html

https://tirto.id/update-corona-indonesia-21-april-2020-data-covid-19-dunia-terkini-ePYZ 